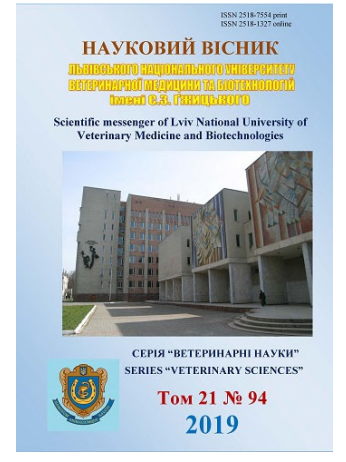

Науковий вісник Аьвівського національного університету ветеринарної медицини та біотехнологій імені С.3. Гжицького.

$$
\text { Серія: Ветеринарні науки }
$$

Scientific Messenger of Lviv National University of Veterinary Medicine and Biotechnologies.

Series: Veterinary sciences

\title{
Industrial tests of different methods of soil samples testing for the presence of eggs of nematodes - pathogens of parasitic diseases of sheep
}

\author{
V.V. Melnychuk, I.D. Yuskiv \\ Stepan Gzhytskyi National University of Veterinary Medicine and Biotechnologies Lviv, Ukraine
}

Article info

Received 19.03.2019

Received in revised form 19.04.2019

Accepted 22.04.2019

Stepan Gzhytskyi National University of Veterinary Medicine and Biotechnologies Lviv, Pekarska Str., 50, Lviv, 79010, Ukraine.

Tel.:+38-066-674-78-09 E-mail:melnychyk86@ukr.net
Melnychuk, V.V., \& Yuskiv, I.D. (2019). Industrial tests of different methods of soil samples testing for the presence of eggs of nematodes - pathogens of parasitic diseases of sheep. Scientific Messenger of Lviv National University of Veterinary Medicine and Biotechnologies. Series: Veterinary sciences, 21(94), 9-14. doi: 10.32718/nvlvet9402

Under current conditions, livestock farming, where a large number of animals are kept in restricted areas, creates all the prerequisites for intensive parasitic contamination of the environment. The objects of the environment, including the soil, are an important link in the development of pathogens of parasitic diseases. Out of all objects, soil plays a major role in the emergence of invasive diseases, since it is the main factor in the transmission of diseases. In this regard, the issue of studying contamination of soil with invasive elements remains relevant. Knowledge of the level of soil contamination with invasive elements enables to develop strategies for conducting economic activity taking into account its actual pollution and to plan well-grounded measures to overcome invasive diseases. However, it remains important to choose an effective research method, which today has a large number. In this regard, the purpose of our research was to find out the sensitivity of the methods of soil study on nematode eggs, in particular regarding the digestive system strontium, and the species Trichuris sp., S. papillosus, S. ovis and A. bovis. The obtained data indicate that the use of well-known (Romanenko-Hudzhabidze, Dolbin et al.) and advanced methods of sanitary-parasitological research proved to be suitable for the establishment of soil contamination by eggs of nematodes. However, the most effective method was the improved method, as it allows to detect the greatest number of nematode eggs in the samples under investigation (by 30.41 and $68.21 \%$, as compared with the methods of Dolbin et al. and Romanenko-Gudzhabidze, respectively). In addition, the proposed method is more effective than the number of eggs per $\mathrm{kg}$ of soil (30.41 and 64.68\%, respectively, for Dolbin et al. and Romanenko-Gudzhabidze). The high efficiency of the new method is also confirmed by the indicators of the ommogram, according to which it allows to find in the samples of soil eggs the strontium of the digestive organs, in particular Nematodirus sp., as well as nematodes of species Trichuris sp., S. papillosus, S. ovis, A. bovis. Their number was higher than Dolbin et al. and Romanenko-Gudzhabidze. Thus, the data obtained have an important theoretical and practical significance, since they allow a wellgrounded choice of the method of soil study to establish its contamination with nematode eggs, taking into account the effectiveness of a particular species of the parasite.

Key words: soil research, efficiency, contamination, egg nematodes, efficiency of the method.

\section{Виробничі випробування різних способів дослідження проб грунту на наявність яєць нематод - збудників паразитарних захворювань овець}

\author{
В.В. Мельничук, І.Д. Юськів
}

Львівський національний університет ветеринарної медицини та біотехнологій імені С.3. Гжицького, м. Львів, Украӥна

За сучасних умов ведення галузі тваринництва, де на обмежених територіях утримується значна кількість тварин, створюються всі передумови до появи інтенсивного паразитарного забруднення зовнішнього середовища. Об'єкти довкілля, у тому числі 
й трунт - важлива ланка у ииклі розвитку збудників паразитарних захворювань. Із всіх предметів та об'єктів трунт відіграє найсуттєвішу роль у появі інвазійних захворювань, оскільки є основним із факторів передачі хвороб. У зв'язку з ичим актуальним залишається питання вивчення контамінації грунту інвазійними елементами. Знання рівня контамінації грунту інвазійними елементами дає змогу здійснювати розробку стратегій ведення господарської діяльності з урахуванням його фактичного забруднення та проводити планування обтрунтованих заходів з метою подолання інвазійних хвороб. Однак важливим залишається питання вибору ефективного способу дослідження, яких на сьогодні існує велика кількість. У зв'язку з цим метою наших досліджень було з'ясувати чутливість способів дослідження трунту щчодо яєць нематод, зокрема стронгілят органів травлення, а також видів Trichuris sp., S. papillosus, S. оvis та A. bоvis. Отримані дані свідчать, щзо використання загальновідомих (Романенко-Гуджабидзе, Долбіна й ін.) та удосконаленого способів санітарно-паразитологічних досліджень виявилися придатними для встановлення контамінації трунту яйцями нематод. Однак за кількісним показником найбільш ефективним виявився удосконалений спосіб, оскільки він дозволяє виявити найбільиу кількість яєць нематод у досліджуваних зразках (на 30,41 та 68,21\% порівняно зі способами Долбіна й ін. та Романенко-Гуджабідзе відповідно). Також запропонований спосіб є ефективнішим за показником кількості яєць у перерахунку на кг трунту (на 30,41 та 64,68\% порівняно зі способами Долбіна й ін. та Романенко-Гуджабідзе відповідно). Висока ефективність нового способу підтверджується й показниками омограми, згідно з якою він дозволяє виявляти в пробах грунту яйця стронгілят органів травлення, зокрема Neтatodirus sp., а також нематод видів Trichuris sp., S. papillosus, S. ovis, A. bovis. Ïx кількість була вищою порівняно зі способами Долбіна й ін. та Романенко-Гуджабідзе. Таким чином, отримані дані мають важливе теоретичне та практичне значення, оскільки дозволяють здійснити обтрунтований вибір способу дослідження трунту з метою встановлення його контамінації яйцями нематод з урахуванням ефективності до того чи іншого виду паразита.

Ключові слова: дослідження трунту, ефективність, контамінація, яйця нематод, ефективність способу.

\section{Вступ}

Паразитарне забруднення об'єктів довкілля яйцями гельмінтів нині залишається важливим питанням для фахівців різних галузей, у тому числі й лікарів ветеринарної медицини, що потребує додаткового вивчення (Roeber et al., 2013; Stets \& Voloshyna, 2016). Загальновідомо, що до найбільш контамінованих інвазійними елементами об'єктів довкілля належить грунт, особливо його поверхневі шари. Згідно з літературними даними, для нематод, які є геогельмінтами, грунт відіграє важливе значення у циклі біологічного розвитку (Gaasenbeek \& Borgsteede, 1998; Dubná et al., 2007; Romero et al., 2010).

Збудники паразитарних захворювань на різних стадіях екзогенного розвитку мають широке розповсюдження у зовнішньому середовищі. При цьому вони здатні довго час залишатися у життєздатному стані, не втрачаючи інвазійної здатності (Dubey, 1998; Lassen et al., 2013). У зв'язку з вищенаведеним, системний моніторинг за рівнем контамінації довкілля, особливо місць утримання тварин, є одним з основних моментів, які необхідно включати у систему заходів, спрямованих на лікування та профілактику паразитарних хвороб тварин (Collender et al., 2015; Steinbaum et al., 2016; Amoah et al., 2017).

На сьогодні у доступній науковій літературі дослідники 3 різних країн світу пропонують способи та методи, спрямовані на вивчення рівня паразитарного забруднення довкілля. Варто зазначити, що більшість запропонованих способів грунтуються на флотаційній здатності використовуваних розчинів (Dada, 1979; Loh \& Israf, 1998; Zilberman et al., 2009; Oge \& Oge, 2010). Водночас, науковці, пропонуючи власні методики досліджень грунту, орієнтувалися на виявлення конкретного виду збудника (Barwick et al., 2000; Lélu et al., 2011; Sroka et al., 2018). У зв'язку з цим відкритим залишається питання чутливості пропонованих методик до яєць чи ооцист інших видів паразитів.

Враховуючи вищенаведене, вважаємо, що дослідження 3 приводу визначення ефективності різних способів дослідження грунту з метою встановлення рівня паразитарного обсіменіння $є$ актуальним напрямом роботи. Тому метою наших досліджень було з'ясувати чутливість способів дослідження грунту щодо яєць нематод - збудників паразитарних захворювань овець.

\section{Матеріал і методи досліджень}

Дослідження проводили упродовж 2018 р. на базі лабораторії кафедри паразитології та ветеринарносанітарної експертизи Полтавської державної аграрної академії.

3 метою визначення ефективності удосконаленого та загальновідомих способів дослідження грунту на наявність яєць нематод різних видів проведено виробниче дослідження. В умовах вівцегосподарств Полтавської області відбирали проби поверхневого шару грунту (з місць утримання та випасання овець) згідно 3 загальноприйнятими методиками. Усі проби досліджували на наявність яєць нематод за методом Романенко (1968) та Гуджабідзе (1969). Із загальної кількості проб відібрано 20 зразків, у яких одночасно виявляли яйця нематод ряду Strongylida (зокрема Nematodirus sp.), видів Trichuris sp., S. papillosus, S. ovis та A. bovis. Одну й ту ж пробу досліджували за методом: Романенко-Гуджабідзе (Kotelnikov, 1984); Долбіна та ін. (Dolbin et al., 2014) та запропонованим удосконаленим способом (за основу взято спосіб Романенко-Гуджабідзе). Показниками ефективності визначено: кількість позитивних проб, загальна кількість виявлених інвазійних елементів у досліджуваних пробах, кількість у перерахунку на 1 кг грунту (екз./кг), їхні мінімальні та максимальні значення.

Статистичну обробку отриманих результатів експериментальних досліджень здійснювали шляхом визначення середнього арифметичного (M) та його похибки (m).

\section{Результати та їх обговорення}

За результатами експериментальних досліджень встановлено, що найбільш ефективним 3 метою вияв- 
лення яєць нематод у пробах грунту виявився запропонований спосіб (табл. 1).

Зареєстровано, що спосіб Романенко-Гуджабідзе за його застосування у виробничих дослідженнях проявив найнижчі результати ефективності. Так, з 20ти досліджуваних проб позитивними виявилось 18 . Тобто, за показником кількості позитивних проб ефективність способу склала 90\%. Загалом у досліджуваних пробах виявлено 2750 екз. яєць нематод, що в середньому склало $152,78 \pm 14,66$ екз./кг проби грунту, за коливань від 40 до 260 яєць/кг.
Кращі показники отримано за використання способу Долбіна та ін. Так, спосіб проявив 100\% ефективність за кількістю позитивних проб відносно досліджуваних. Зі збільшенням числа позитивних проб також підвищувалася й загальна кількість виявлених яєць нематод, яка сягнула 6020 екз., що на 54,32\% більше порівняно з попереднім способом. Варто зазначити, що в середньому кількість яєць нематод у одній пробі грунту склала $301,00 \pm 17,29$ екз./кг (на 49,24\% більше порівняно з попереднім способом), за коливань від 140 до 530 яєць/кг.

\section{Таблиця 1}

Порівняльна ефективність різних способів дослідження проб грунту з метою виявлення яєць нематод, $\mathrm{n}=20$

\begin{tabular}{lcccc}
\hline \multicolumn{1}{c}{ Спосіб дослідження } & Кількість позитивних & \multicolumn{3}{c}{ Виявлено яєць нематод } \\
\cline { 3 - 5 } & проб, екз./\% & всього, екз. & М \pm m, екз./кг & $\min -$ max, екз./кг \\
\hline Романенко (1968) та Гуджабідзе (1969) & $18 / 90,0$ & 2750 & $152,78 \pm 14,66$ & $40-260$ \\
Долбіна та ін. (2012) & $20 / 100,0$ & 6020 & $301,00 \pm 17,29$ & $140-530$ \\
Запропонований спосіб & $20 / 100,0$ & 8650 & $432,50 \pm 28,85$ & $150-675$ \\
\hline
\end{tabular}

Використання запропонованого способу дослідження виявилося найбільш ефективним. Як і в попередньому випадку, з 20-ти досліджуваних проб всі виявилися позитивними. За використання способу в досліджуваних пробах зафіксовано найбільшу кількість яєць нематод - 8650 екз., що на 30,41 та 68,21\% більше порівняно зі способами Долбіна й ін. та Романенко-Гуджабідзе відповідно. Також збільшилося й середнє число яєць нематод в одній пробі та в середньому становило 432,50 $\pm 28,85$ екз./кг досліджуваного грунту (на 30,41 та 64,68\% більше порівняно зі способами Долбіна й ін. та Романенко-Гуджабідзе відповідно), за коливань від 150 до 675 яєць/кг.

Таким чином, дослідження проб грунту з використанням запропонованого способу за кількісним показником виявилося найбільш ефективним порівняно із загальновідомими способами Долбіна й ін. та Романенко-Гуджабідзе.

Незважаючи на відносну схожість способів у послідовності виконання, за наслідками овограми встановлено, що всі вони володіють неоднаковою ефективністю щодо виявлення яєць нематод різних таксономічних одиниць (табл. 2, рис. 1).

\section{Таблиця 2}

Результати овограми за використання різних способів дослідження проб грунту на наявність яєць нематод, $\mathrm{n}=20$

\begin{tabular}{|c|c|c|c|c|}
\hline \multirow{2}{*}{ Спосіб } & \multirow{2}{*}{ Інвазійні елементи збудника } & \multirow{2}{*}{$\begin{array}{c}\text { Позитивних проб, } \\
\text { екз./\% }\end{array}$} & \multicolumn{2}{|c|}{ Виявлено яєць } \\
\hline & & & всього, екз. & $\mathrm{M} \pm \mathrm{m}$, екз./кг \\
\hline \multirow{5}{*}{ Романенко-Гуджабідзе } & Стронгіляти органів травлення & $18 / 90$ & 1750 & $97,22 \pm 12,12$ \\
\hline & у т. ч. Nematodirus $s p$. & $13 / 65$ & 530 & $40,77 \pm 6,35$ \\
\hline & Trichuris sp. & $13 / 65$ & 580 & $44,62 \pm 7,65$ \\
\hline & S. papillosus & $8 / 40$ & 210 & $26,25 \pm 4,60$ \\
\hline & S. ovis & $7 / 35$ & 210 & $30,00 \pm 6,55$ \\
\hline \multirow{6}{*}{ Долбіна та ін. } & Стронгіляти органів травлення & $20 / 100$ & 3540 & $177,00 \pm 12,31$ \\
\hline & у т. ч. Nematodirus $s p$. & $15 / 75$ & 1020 & $68,00 \pm 8,57$ \\
\hline & Trichuris $s p$. & $19 / 95$ & 1280 & $67,37 \pm 7,64$ \\
\hline & S. papillosus & $14 / 70$ & 660 & $47,14 \pm 7,12$ \\
\hline & S. ovis & $10 / 50$ & 320 & $32,00 \pm 6,11$ \\
\hline & A. bovis & $6 / 30$ & 220 & $36,67 \pm 9,55$ \\
\hline \multirow{6}{*}{ Запропонований } & Стронгіляти органів травлення & $20 / 100$ & 4250 & $212,50 \pm 20,78$ \\
\hline & у т. ч. Nematodirus sp. & $18 / 90$ & 1450 & $80,56 \pm 11,62$ \\
\hline & Trichuris sp. & $20 / 100$ & 1975 & $98,75 \pm 10,13$ \\
\hline & S. papillosus & $16 / 80$ & 1175 & $73,44 \pm 11,17$ \\
\hline & S. ovis & $14 / 70$ & 700 & $50,00 \pm 8,49$ \\
\hline & A. bovis & $11 / 55$ & 550 & $50,00 \pm 10,25$ \\
\hline
\end{tabular}

Так, використання способу Романенко-Гуджабідзе призводило до виявлення у пробах грунту яєць нематод збудників нематодозів травного каналу овець, що належить до 4 рядів: Trichurida, Strongylida, Rhabditida та Oxyurida. Так, у 18 пробах (90\%) виявлено яйця стронгілят травного каналу, загальна кількість яких становила 1750 екз., що в середньому склало 97,22 \pm 12,12 екз./кг досліджуваного грунту. Серед яєць стро- 
нгілят в 13 пробах (65\%) було зареєстровано яйця нематод роду Nematodirus, загальна кількість яких склала 530 екз., що в середньому склало 40,77 \pm 6,35 екз./кг проби грунту.

Окрім стронгілят, в 13 пробах (65\%) виявляли яйця нематод представників ряду Trichurida Trichuris sp. у кількості 580 екз., що в середньому склало 44,62 \pm 7,65 екз./кг грунту. Яйця представників ряду Rhabditida та Oxyurida - S. papillosus та S. ovis реєстрували у 8 та 7 пробах відповідно (40 та 35\%), загальна кількість інвазійних елементів для кожного 3 них становила 210 екз., що в середньому склало для яєць стронгілоїдесів - 26,25 \pm 4,60 екз./кг, а для скрябінем $-30,00 \pm 6,55$ екз./кг.

Аналізуючи показники овограми за використання способу Долбіна й ін. встановлено, що вказана методика дозволяє виявити яйця нематод представників 5 рядів, а саме: Trichurida, Enoplida, Strongylida, Rhabditida та Oxyurida. Яйця стронгілят травного каналу овець виявлено у 20 пробах грунту (100\%), загальна їх кількість сягала 3540 екз., що в середньому склало $177,00 \pm 12,31$ екз./кг. Варто зауважити, що серед яєць стронгілят за морфологічною будовою у 15 пробах (75\%) було диференційовано яйця нематод роду Nematodirus, загальна кількість останніх досягала 1020 екз., що в середньому склало 68,00 \pm 8,57 екз./кг проби грунту. Варто зауважити, що досить часто (95 та 70\%) у пробах грунту виявляли яйця нематод видів Trichuris sp. та S. papillosus, у 19 та 14 пробах відповідно, їх кількість сягала 1280 та 660 екз., що в середньому складало $63,37 \pm 7,64$ та 47,14 \pm 7,12 екз./кг. Менше реєстрували яйця нематод видів S. ovis та A. bovis - у 10 та 6 пробах грунту яєць відповідно (50 та 30\%), загальна кількість яких становила 320 та 220 екз., що в середньому склало $32,00 \pm 6,11$ та $36,67 \pm 9,55$ екз./кг у пробі грунту.
Використання пропонованого способу дозволило отримати найкращу ефективність показників овограми. Яйця стронгілят травного тракту овець зареєстровано у 20 пробах грунту (100\%), загальна кількість виявлених у пробах грунту досягла 4250 екз. В середньому у кілограмі грунту виявляли $212,50 \pm 20,78$ екз. яєць. Поряд з тим, у 18 пробах (90\%), серед яєць стронгілят травного каналу виявляли яйця нематодірусів, загальна кількість яких становила 1450 екз., що в середньому склало $80,56 \pm 11,62$ екз./кг проби грунту. Також, у 100\% досліджуваних проб грунту виявляли яйця трихурисів, загалом їх було виявлено у кількості 1975 екз., що в середньому на кг грунту склало 98,75 $\pm 10,13$ екз. Дещо менше (80 та 70\%) виявляли яйця стронгілоїдесів та скрябінем, у 16 та 14 пробах. Загальна кількість яєць вказаних видів становила 1175 та 700 екз., що в середньому складало $73,44 \pm 11,17$ та 50,00 \pm 8,49 екз./кг досліджуваного грунту. Що стосується яєць збуднику виду A. bovis, то їх виявляли у 11 пробах (55\%), загальна кількість яєць капілярій, виявлених в усіх позитивних пробах становила 550 екз., що в середньому склало $50,00 \pm 10,25$ екз./кг грунту.

Таким чином, характеризуючи способи дослідження проб грунту, можна зробити висновок, що за всіма досліджуваними характеристиками запропонований спосіб мав найвищі показники.

Як видно з рис. 1, за числом позитивних проб запропонований спосіб виявився ефективнішим за методики Романенко-Гуджабідзе та Долбіна й ін. при виявлення яєць нематод видів: A. bovis (на 100 та $45,5 \%$ ), S. ovis (на 50,0 та 28,5\%), S. papillosus (на 50,0 та $12,5 \%$ ), Trichuris sp. (на 35,0 та 5,0\%), ряду Strongylida (на 10,0\%), зокрема роду Nematodirus (на 27,8 та $16,7 \%$ ).

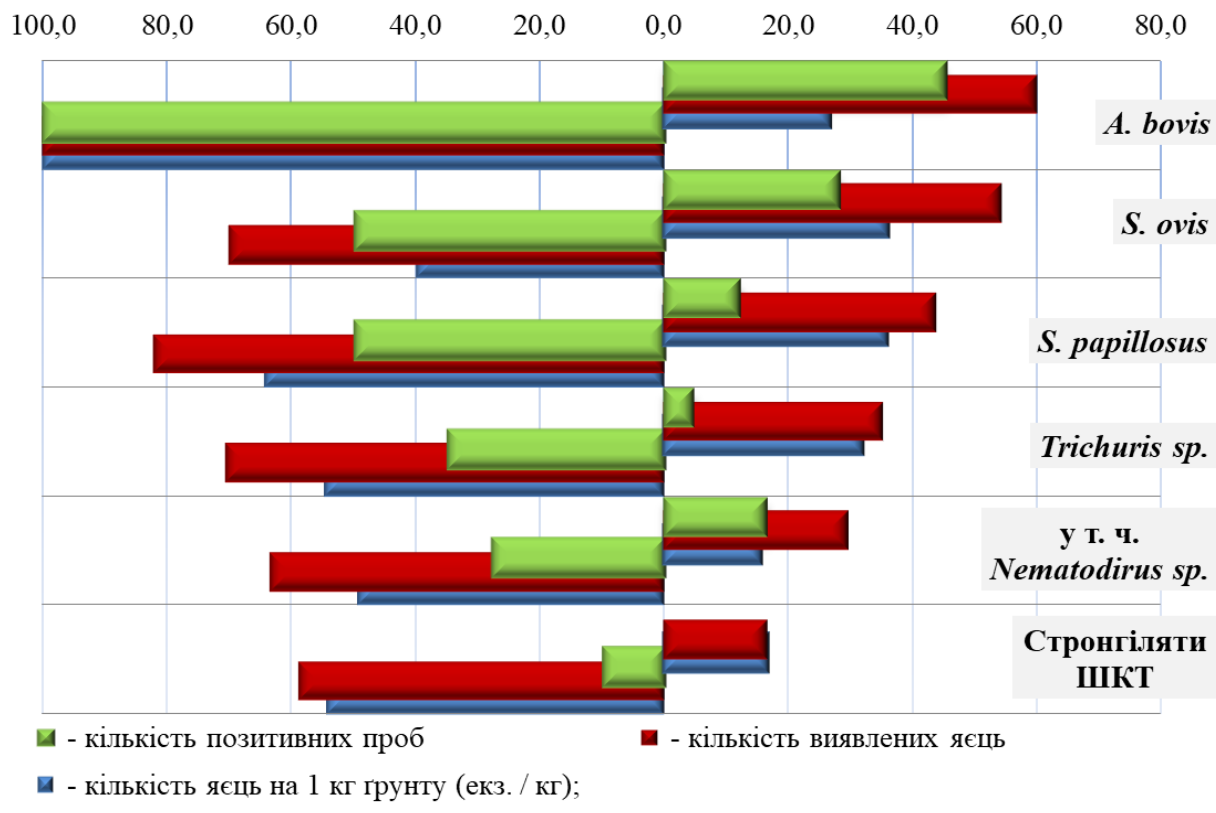

Рис. 1. Ефективність удосконаленого способу дослідження проб грунту відносно загальновідомих, \%: зліва - спосіб Романенко-Гуджабідзе; справа - спосіб Долбіна й ін. 
Запропонований спосіб також виявився ефективнішим за методики Романенко-Гуджабідзе та Долбіна й ін. за показником загальної кількості виявлених у пробах яєць нематод видів: A. bovis (на 100,0 та $60,0 \%$ ), S. ovis (на 70,0 та 54,3\%), S. papillosus (на 82,1 та 43,8\%), Trichuris sp. (на 70,6 та $35,2 \%$ ), ряду Strongylida (на 58,8 та $16,7 \%$ ), зокрема роду Nematodirus (на 63,5 та 29,7\%).

Варто зазначити, що ефективність запропонованого способу також підтверджувалась показниками кількості виявлених яєць нематод у перерахунку на 1 кг грунту (екз./кг). Згідно з дослідженнями, спосіб виявився ефективнішим за методики РоманенкоГуджабідзе й Долбіна та ін. щодо яєць нематод видів: A. bovis (на 100,0 та 26,7\%), S. ovis (на 40,0 та $36,0 \%$ ), S. papillosus (на 64,3 та 35,8\%), Trichuris sp. (на 54,8 та $31,8 \%$ ), ряду Strongylida (на 54,3 та $16,7 \%$ ), зокрема роду Nematodirus (на 49,4 та 15,6\%).

Отже, за показниками ефективності запропонований спосіб перевищує ефективність загальновідомих методів і тому може бути рекомендований для встановлення контамінації грунту яйцями нематод.

Впровадження у практику нових високоефективних способів досліджень об'єктів довкілля, у тому числі й грунту, з метою виявлення інвазійних елементів $є$ актуальним напрямом, над яким активно працюють науковці багатьох країн світу (Dada, 1979; Novozhilov, 2014; Collender et al., 2015). Варто зазначити, що в Україні робіт, пов'язаних з удосконаленням способів дослідження проб грунту та вивченням їх ефективності у виробничих умовах, не виявлено. Тому актуальність проведених нами досліджень не викликає сумніву.

Отримані нами дані свідчать, що використовувані санітарно-паразитологічні способи дослідження виявилися придатними для встановлення контамінації грунту яйцями нематод, що знаходить підтвердження у роботах науковців (Dolbin et al., 2014; Novozhilov \& Chernikova, 2014). Водночас у нашій роботі наведені дані щодо ефективності як загальновідомих способів дослідження грунту, так й авторської розробки. Автентичність проведених досліджень полягає у тому, що у роботі запропоновано удосконалений спосіб дослідження грунту з метою виявлення яєць нематод. Окрім того, наведено дані відносно ефективності запропонованого та відомих способів дослідження грунту щодо яєць нематод, які належать до ряду Strongylida (зокрема Nematodirus sp.) та видів Trichuris sp., S. papillosus, S. ovis, A. bovis - збудників паразитарних захворювань овець.

Таким чином, отримані дані дозволяють здійснити обгрунтований вибір способу дослідження грунту 3 метою встановлення його контамінації яйцями нематод з урахуванням ефективності до того чи іншого виду паразита.

\section{Висновки}

В умовах виробничих випробувань встановлено, що загальновідомі санітарно-паразитологічні способи дослідження грунту Романенко-Гуджабідзе, Долбіна й ін., а також удосконалений спосіб володіють здатністю виявляти яйця нематод. Доведено, що удосконалений спосіб дослідження грунту виявився ефективнішим порівняно зі способами Романенко-Гуджабідзе та Долбіна й ін. за показниками кількості виявлених яєць нематод у досліджуваних зразках (на 30,41 та 68,21\% відповідно) та їх кількістю у перерахунку на кг грунту (на 30,41 та 64,68\% відповідно). Також зафіксовано, що удосконалений спосіб є більш чутливим порівняно зі способами Романенко-Гуджабідзе та Долбіна й ін., при виявлення яєць нематод різних таксономічних одиниць: Strongylida (на 10,0-58,8\%); Nematodirus (на 16,7-63,5\%); Trichuris (на 5,0-70,6\%); S. papillosus (на 12,5-82,1\%); S. ovis (на 28,5-70,0\%); A. bovis (на 26,7-100,0\%), за показниками кількості позитивних проб, загальної кількості виявлених інвазійних елементів у досліджуваних пробах та їх кількістю в перерахунку на 1 кг грунту.

Перспективи подальших досліджень. Проведені дослідження $є$ передумовою для проведення комплексного дослідження грунту території вівцегосподарств 3 метою встановлення рівня паразитарного забруднення.

\section{References}

Amoah, I.D., Singh, G., Stenström, T.A., \& Reddy, P. (2017). Detection and quantification of soiltransmitted helminths in environmental samples: A review of current state-of-the-art and future perspectives. Acta Tropica, 169, 187-201. doi: 10.1016/j.actatropica.2017.02.014.

Barwick, R.S., Mohammed, H.O., White, M.E., \& Bryant, R.B. (2000). Detection of Cryptosporidium parvum and Cryptosporidium muris in soil samples. Biology and Fertility of Soils, 31(5), 385-390. doi: 10.1007/s003749900185.

Collender, P.A., Kirby, A.E., Addiss, D.G., Freeman, M.C., \& Remais, J.V. (2015). Methods for Quantification of Soil-Transmitted Helminths in Environmental Media: Current Techniques and Recent Advances. Trends in Parasitology, 31(12), 625-639. doi: 10.1016\%2Fj.pt.2015.08.007.

Dada, B.J.O. (1979). A new technique for the recovery of Toxocara eggs from soil. Journal of Helminthology, 53(2), 141-144. doi: 10.1017/s0022149x00005873.

Dolbin, D.A., Lutfullin, M.H., \& Sokolina, F.M. (2014). Obsledovanija pochvy na jajca gel'mintov. Rossijskij parazitologicheskij zhurnal, 2, 70-76 (in Russian).

Drab, R.R., Guschuk, I.V., Safonov, R.V., Byalkovsky, A.V., \& Brezetska, O.I. (2017). Monitoring the epidemic process at geohelminthism among children in Rivne region. CHILD 'S HEALTH, 12(3), 360-365. doi: 10.22141/2224-0551.12.3.2017.104227.

Dubey, J.P. (1998). Toxoplasma gondii Oocyst Survival under Defined Temperatures. The Journal of Parasitology, 84(4), 862-865. doi: 10.2307/3284606.

Dubná, S., Langrová, I., Jankovská, I., Vadlejcha, J., Pekárb, S., Nápravníka, J., \& Fechtner, J. (2007). 
Contamination of soil with Toxocara eggs in urban (Prague) and rural areas in the Czech Republic. Veterinary Parasitology, 144(1-2), 81-86. doi: 10.1016/j.vetpar.2006.09.023.

Gaasenbeek, C. P., \& Borgsteede, F.H. (1998). Studies on the survival of Ascaris suum eggs under laboratory and simulated field conditions. Veterinary Parasitology, 75(2-3), 227-234. doi: 10.1016/s03044017(97)00198-2.

Kotelnikov, G.A. (1984). Gelmintologicheskie issledovanija zhivotnykh i okruzhajushchej sredy. Moscow: Kolos (in Russian).

Lassen, B., Lepik, T., \& Bangoura, B. (2013). Persistence of Eimeria bovis in soil. Parasitology Research, 112(7), 2481-2486. doi: 10.1007/s00436-013-3413-4.

Lélu, M., Gilot-Fromont, E., Aubert, D., Richaume, A., Afonso, E., Dupuis, E., Gotteland, C., Marnef, F., Poulle, M. L., Dumètre, A., Thulliez, P., Dardé, M.L., \& Villena, I. (2011). Development of a sensitive method for Toxoplasma gondii oocyst extraction in soil. Veterinary Parasitology, 183 (1-2), 59-67. doi: 10.1016/j.vetpar.2011.06.018.

Loh, A.G., \& Israf, D.A. (1998). Tests on the centrifugal flotation technique and its use in estimating the prevalence of Toxocara in soil samples from urban and suburban areas of Malaysia. Journal of Helminthology, 72(01), 39. doi: 10.1017/s0022149x0000095x.

Novozhilov, K.A., \& Chernikova, E.A. (2014). Aktual'nost' i sovershenstvovanie sanitarnogel'mintologicheskikh metodov issledovaniya pochvy. Meditsinskaya parazitologiya i parazitarnye bolezni, 1 , 58-59 (in Russian).

Novozhilov, K.A. (2014). Optimizacija metodov sanitarno-parazitologicheskih issledovanij obektov sredy obitanija cheloveka: diss. ... kand. med. nauk: 03.02.11. Moskva, 99 (in Russian).
Oge, H., \& Oge, S. (2000). Quantitative comparison of various methods for detecting eggs of Toxocara canis in samples of sand. Veterinary Parasitology, 92(1), 75-79. doi: 10.1016/s0304-4017(00)00276-4.

Roeber, F., Jex, A.R., \& Gasser, R.B. (2013). Impact of gastrointestinal parasitic nematodes of sheep, and the role of advanced molecular tools for exploring epidemiology and drug resistance - An Australian perspective. Parasites \& Vectors, 6(1), 153. doi: 10.1186/1756-3305-6-153.

Romero, C., Mendoza, G.D., Bustamante, L.P., Yanez, S., \& Ramirez, N. (2010). Contamination and Viability of Toxocara $s p$. in Feces Collected from Public Parks, Streets and Dogs in Tejupilco at the Subhumid Tropic of Mexico. Journal of Animal and Veterinary Advances, 9(23), 2996-2999. doi: 10.3923/javaa.2010.2996.2999.

Sroka, J., Karamon, J., Dutkiewicz, J., Wójcik-Fatla, A., \& Cencek, T. (2018). Optimization of flotation, DNA extraction and PCR methods for detection of Toxoplasma gondii oocysts in cat faeces. Annals of Agricultural and Environmental Medicine, 25(4), 680-685. doi: 10.26444/aaem/97402.

Steinbaum, L., Njenga, S.M., Kihara, J., Boehm, A.B., Davis, J., Null, C., \& Pickering, A.J. (2016). SoilTransmitted Helminth Eggs Are Present in Soil at Multiple Locations within Households in Rural Kenya. PLOS ONE, 11(6), e0157780. doi: 10.1371/journal.pone.0157780.

Stets, G., \& Voloshyna, N. (2016). Toxocara canis Bioindicator of Parasitic Soil Contamination of Technogenically Transformed Territories. The Advanced Science Journal, 2016(3), 41-44. doi: 10.15550/asj.2016.03.041.

Zilberman, A., Zimmels, Y., Starosvetsky, J., Zuckerman, U., \& Armon, R. (2009). A Two-Phase Separation Method for Recovery of Cryptosporidium Oocysts from Soil Samples. Water, Air, and Soil Pollution, 203(1-4), 325-334. doi: 10.1007/s11270-009-0015-y. 